\title{
The ethics of dental practice in London in the sixteenth century. 1. Henry Chettle's Kind-Harts dreame of 1592. An important lay view.
}

IN BRIEF
Provides the first ethical discussion of
dental practice in England from a lay
viewpoint.
Discusses how dental operators in the
sixteenth century were encouraged to
have a self-respecting and self-governing
discipline.
Clarifies understanding of the 'tooth-
worm'

\section{Bishop ${ }^{1}$}

Kind-Harts dreame (Fig. 1) is one of the proto-novels which first appeared in the Elizabethan age of literary wonders. It recounts the dream of the hero - a tooth-drawer (Kind-Hart) - who encounters the shades of five recently deceased characters, each of whom had been a famous star of their day in the London scene. Although short, and with medicine and dentistry occupying only part of the tale, the story contains invaluable detailed information about dental care in late Tudor England as observed by a layman. It is also an amusing read.

\section{INTRODUCTION}

\section{The author}

Henry Chettle (c. 1563-1607) was an interesting character. A contemporary of William Shakespeare and a possible collaborator with him, he wrote pamphlets and plays; 'an Elizabethan playgoer's staple diet was in large measure provided by hacks like Chettle. ${ }^{1}$ As to his appearance, towards the end of his life he was described as 'sweating and blowing by reason of his fatnes'."

Kind-Hart, his hero, is well enough known to 'his hostisse' for her to put him, after too much 'carowsing, in a pleasant parlor, laid softly on a downe bed, and covered with equal furniture', in 'a taphouse of antiquitie, not far from Finsburie.' ${ }^{3}$ The Manor of Finsbury was two streets away from Grub Street, and to identify Chettle with the 'jack of all trades' Grub Street journalists of later years is not

*'in comes Chettle [to the Elysian Fields], sweating and blowing, by reason of his fatnes; to welcome whom, because hee was an old acquaintance, all rose up, [Marlow, Greene, Peele and Nash] and fell presentlie on their knees, to drink a health to all the Lovers of Helicon [Helicon is a mountain range in Boeotia sacred to the Muses]'.

'Bulls Mill House, Hertford, SG14 3NS

Correspondence to: Malcolm Bishop

Email:malcolmbishop57@btinternet.com

\section{Refereed Paper}

Accepted 19 April 2012

DOI: 10.1038/sj.bdj.2012.557

${ }^{\circledR}$ British Dental Journal 2012; 212: 27-30 inappropriate. Often in debt and borrowing from his friends, he would turn his hand to anything.

From his plays he gained a reputation for comedy, and in a work written to entertain, as well as to inform an educated readership, Chettle shares at least a little quiet smile with his subject when he pictures a man who takes himself and his occupation seriously. Shakespeare furnishes a suitable epitaph: 'jesters do oft prove prophets. ${ }^{3 \dagger}$

\section{The book}

It is a pleasure to find a layman writing about dentistry, particularly when, as here, the account is well-informed. Leaving aside the oddities in spelling and phrasing, the content does not seem old-fashioned in the way that technical medical writings of the Elizabethan period do. In fact, the story has clear modern resonances.

The work is a mixture of a long short story (some 14,000 words), with what could fairly be termed investigative journalism. Called by Chettle himself a "toye'5 and described as a tract in 1841, it is grouped by modern scholarship in what is termed euphuistic literature. It is a further mark of its position in the transition of Elizabethan literary works into a modern setting that the introduction is printed in

'Shakespeare may have contributed part of the Chettle, Munday et al. play Sir Thomas More (not dated). See Shakespeare Society (Great Britain). The Book of Sir Thomas More. London: Shakespeare Society, 1844.

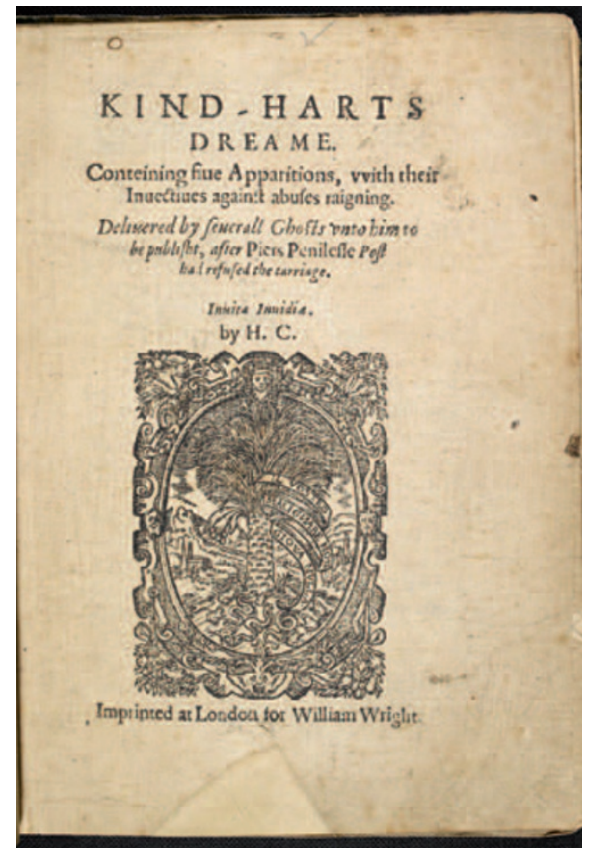

Fig. 1 Title page of Kind-Harts dreame by Henry Chettle, 1592. Image credited to @British Library Board, C14 ab

an easily read typeface, whereas the story itself is printed in black-letter.

Between its publication in 1592 and a scholarly reprint with many valuable footnotes for the Percy Society in 1841, the Dreame had become extremely rare, with only three extant copies known. ${ }^{6}$ We are fortunate that it has survived. A further scholarly reprint was published in an edition by G. B. Harrison in 1923 for the Bodley Head Quartos, which was itself reprinted in 1966 by the Edinburgh University Press. 
Increasing interest in the work was marked in 1997 by a close analysis from the point of view of early English publishing by Alexandra Halasz in her book The marketplace of print pamphlets and the public sphere in early modern England, ${ }^{7}$ in which she contributes a useful comment on Chettle's tooth-drawer.

Now Chettle's work is freely accessible to anyone interested through internet publication. ${ }^{8}$

As mentioned previously, five ghosts visit Kind-Hart as he sleeps, each a famous figure recently deceased, and each a character that a Londoner of Kind-Hart's occupation would have known about as 'stars' of their day. Three are entertainers; Richard Tarlton (d. 1588) actor and dancer who was memorialised again in Ben Jonson's Bartholomew Fayre of 1614, ${ }^{9}$ William Cuckoe, juggler and conjuror and Anthony 'Now-now' a balladeer. Robert Greene MA was a dramatic poet (1558-1592), and the one in whom we are most interested was Dr Burcot, the physician.

\section{THE DOCTOR}

The real Dr Burcot was Burchard Kranich, who had been born (date unknown) in Germany and was in England by 1553. Although he had died in 1578, his fame was such as to be lasting enough for Chettle to use him as the model of a medical man.

His activities involved mining, metallurgy and assaying, ${ }^{10}$ in addition to his famous medical treatment of the Marchioness of Northampton for jaundice and Queen Elizabeth I for smallpox in 1562. ${ }^{11}$ It is as the Queen's physician that he is of concern to Chettle and the story.

Kind-Hart's first view of him is as amusing as it is important: '[Burcot] had a reverent grace, in habite like a doctor, in his right hand hee helde a compendium of all the famous phisitions and surgions works belonging to Theorike, in his lefte hande a table of all instruments for mans health appertaining to practise.

At the sight of this doctor, you may thinke, gentlemen, Kind-hart was in a piteous case: for I verily beleeved he had beene some rare artist that, taking me for a dead man, had come to anatomise me, but,

"Probably not Anthony Munday, Chettle's collaborator, who was very much alive at the time. Now-now is a nickname acquired from the refrain of a popular song.

taking comfort that my thrumde hat ${ }^{\S}$ had hanging at it the ensignes of my occupation, like a tall fellow (as to me it seemed) I lookte him in the face and beholde him to be Maister Doctor Burcot (though a stranger, yet in England for physicke famous.)'12

Of particular note in this passage is that Chettle, as a layman, portrays Kind-Hart facing Burcot as his peer, 'like a tall fellow' Also of note is that in the dream Kind-Hart assumes that the shade of Burcot (although a physician) has come to dissect him. There may be a hint at an in-joke here, for the legitimate targets for anatomising were convicted felons.

\section{KIND-HART}

Chettle/Kind-Hart makes the demarcation between Burcot and the tooth-drawer very clear:

'This is something like (thought I) if he had said any thing against cousoning toothe drawers that from place to place wander with banners full of horse teeth, to the impairing of Kindharts occupation; but I perceive maister doctor was never a tooth drawer; if he had [been], I know he would have toucht their deceivings. Since he hath let them passe, I greatly passe not; and yet, in regard of the credit of my trade, I care not to have a blow or two with them my selfe, before I looke any further.' ${ }^{13}$

Flattering though the name Kind-Hart (possibly an English corruption of a lowcountries 'Tandarts') may be to our profession's intentions, it is not altogether an expected one and nor did it persist beyond quite a narrow time-frame. KindHart points out the significance of bearing such a name, and at the same time Chettle takes a sly dig at his own occupation as a man of letters:

'Gentlemen and good fellowes, (whose kindness having christened mee with the name of Kind-Hart bindes me in all kind course I can to deserve the continuance of your love) let it not seem strange (I beseech ye) that he, that all the daies of his life hath beene famous for drawing

\section{\$Thrumde hat. Patterned wool with a natural felting. If this was indeed ornamented with extracted teeth, Kind-Hart's attack on Banner bearers with horses teeth is somewhat weakened. An appropriate illustration from an earlier age is to be found at http://www. bl.uk/catalogues/illuminatedmanuscripts/ILLUMIN ASP?Size $=$ midCt $I I I D=40327$.}

"Henry VIII. 24 July 1540, an act concernyng barbours and surgeons to be of one companie. 4 felons a year for anatomies. teeth, should now, in drooping age, hazard contemptible infamie by drawing himself into print. ${ }^{14}$

What is clear is that Chettle uses a term to help his readers identify his protagonist as not just a tooth-drawer, but one with the highest reputation and skill. He had both to be distinguishable from the itinerant advertising quack operators and to appear as a fellow professional beside Burcot without seeming ridiculous.

\section{CHETTLE'S PSYCHOLOGICAL ACUITY}

Most crucially, Chettle shows Kind-Hart as a man who has complete confidence in the integrity of his calling. The tooth-drawer is not concerned with what others think of him, he is comfortable in his 'thrum'd hat' and his skill. There is another revealing passage, minor in itself, but absolutely true to life, where Kind-Hart is upset that patients he has treated gratis because they could not afford to pay, desert him for a quack operator. This behaviour, to which the patient gives not a second's thought, leaves a scar on every dentist (it shouldn't, for such professional activity should be unconditional, but it does) - the patient for whom the practitioner has 'gone the extra mile' and who not only shows no gratitude, but no loyalty either.

'[A] pelting tooth-charmer, having no reason to defend his obscure rules, quite put me to silence before a well learned audience, the one a cobler, the other a carman, the last a collier. These, beeing poore men, had I for pittie often eased of their payne, yet was the remedy I usde somewhat painefull; but not long since they are come acquainted with the charmer I told ye of; he, in charitable consideration of their greefe, promised to ease them, onely with writing and after burning a word or two. ${ }^{15}$

\section{THE QUACK REMEDIES CHETTLE IDENTIFIES}

For the physical pain of his patients KindHart spares few words: 'this I find to be the only remedy for the tooth paine, either to have patience, or to pull them out. ${ }^{16}$

of the three quack remedies for toothache Kind-Hart/Chettle identifies, two were out and out frauds, the other has become a staple of modern dental practice. The fraudulent treatments were the spell type and the henbane scam. 
The spell or charme (which Chettle gives in full) was ostensibly aimed at driving out the 'spirites that enter into the blood and cause rewmes, and consequently the toothach. ${ }^{17}$, That the fever (rewme) which results from a severe dental infection should be mistaken for the cause is understandable, and nearly a century later a case report of a salivary calculus in the Proceedings of the Royal Society ${ }^{18}$ reflected continued belief in the 'taking cold' causation of oral pain.

The quackery lies in the belief in 'spirites'. Chettle is uncompromising in his view of the need for accurate identification of cause before disease can be tackled. In the words of Burcot; 'every disease [has] his beginning; but the remedy riseth from the knowledge of the cause. If any can (in naturall sense) give ease, they must be artistes that are able to search the cause, resist the disease, by providing remedies. ${ }^{, 19}$

The henbane scam (which Chettle describes in detail) also had a basis in observation and like the spell fraud, might have had some psychosomatic benefit, though as Kind-Hart points out, dental pain does not lend itself to such remedies. The scam depended on convincing the sufferer that the worm-like parts of a henbane seed liberated by heat, were tooth-worms. Again, the scam aspect and sound observation can be separated, for as the third quack remedy Chettle details shows, the dental pulp was at the time identified as a worm.

Among the great riches of the records of the Royal Society, now made freely available, is a variant of this, showing that 'smoking' tooth-worms was still practised a hundred years on. In July 1700, Anthony van Leeuwenhoek (1632-1723) investigated three 'little worms pretended [modern English 'said'] to be taken from a corrupt tooth by smoaking' (two were dead, one alive), which had been sent to him from England. They were cheese-mites. ${ }^{20}$

The third quack treatment described by Kind-Hart is as old as Abulcasis" and therefore possibly of even greater antiquity.

Based on sound observation, destroying the exposed pulp of a painful tooth when

\footnotetext{
The 1841 reprint carries other contemporary spells as a footnote; $p 77$

"Abu al-Qasim Khalaf ibn al-Abbas Al-Zahrawi (9361013): a fine Arabic illustration of cautery of the pulp is reproduced in http://www.cardenashistoriamedicina. net/capitulos/es-cap6-2.htm (accessed January 2012).
}

the access cavity is large enough is the early beginning of endodontics. 'Another sort get hot wires, and with them they burn out the worme that so torments the greeved.21 The technique demands a steady hand and eye, and as much courage from the patient as the operator for otherwise 'they would misse the tooth and worme the tongue. ${ }^{21}$

This idea of the 'worme', which creates toothache, is sometimes quoted as a sign of the ignorance of the past. It should more properly be regarded as evidence of sound observation - it is not infrequent that the pulp of an extracted tooth is seen extruded from the apex or apices, appearing very similar to a thread-worm.

Successful cautery would have drawn out a pulp fused to the cooled wire, as to a barbed broach, and 'proved' to patient and operator alike that the worm was out of the tooth and pain would indeed cease.

Chettle was right about the treatment being improper, if for the wrong reasons. It was only the introduction of radiography to dentistry in 1895 and a fuller understanding of the process of infection that made the practic e of endodontics healthy. No operator for centuries to come would have understood the significance of an empty pulp chamber, unsealed at the apex.

\section{KIND-HART'S GOVERNANCE}

Chettle is valuable when he considers the governance of medicine and dentistry. For medicine, authority is already in place and just needs application:

[Chettle]: 'For master doctors motion, I doubt not but those which have charge theretoo to looke, will be verie carefull to discharge their dueties. ${ }^{22}$

[Burcot]: 'Assure your selves, if you refraine not, justice will stand uppe, and so restrine yee, as there shall be nothing more noted than your ignorant practises and impudent courses. In my life I was your adversary; in death I am your enimie. Beseeching the reverend colledge of learned doctors and worshipful company of experienst chirurgeons ${ }^{++}$to look more straightly to your false decites and close haunts, that there may be sooner heard talke of such a rare obscure assurancer, to work what not wonders in phisicke or

\footnotetext{
\#‡Inter alia, Henry VIII. 1540 for physicians and their privilege and Henry VIII 1511. An act for the appointing of physicians and surgeons.
}

chirurgerie, but he be rather lookt into or ever he begin, than suffred to begin, whereby any poore patient should suffer losse in trial of their blind skill: so shall your cousenages be as open as your actes be odious.'23

As for the tooth-drawers, Kind Hart's own position as an acknowledged master carries with it the responsibility to speak out - if he does not have the institutional authority of the physicians or barber-surgeons - he has the moral authority of his standing in the community (comparable with the collective if impersonal position now occupied by the BDA, and in particular the editorial and letters of the BDJ).

In his introductory letter 'to the Gentlemen Readers', Chettle identifies himself very clearly with the words he puts into the mouth of his protagonist.

[Chettle]: 'I beseech yee accept the publicke cause, which is both the desire of your delight and common benefite: for, though the toye bee shadowed under the title of Kind-Harts Dreame, it discovers the false hearts of divers that wake to commit mischief. ${ }^{24}$

[Kind-Hart]: 'My selfe will not be slacke against wandring tooth-drawers...neither will I alone against them inveigh, but generally against all such banner-bearers. ${ }^{25}$

\section{SUMMARY}

Chettle's Kind-Hart not only gives us the first lay view of ethical dental practice in English literature, but places dentistry beside medical practice, if not as an equal profession, one distinct and comparable.

The account is particularly important as it can be contrasted with the medico-legal orthodoxy of the regulations newly established by the Thomas More Ordinances (1530) for the barber-surgeons in London.

Perhaps because the early practitioners of dentistry who were within the discipline of the barber's company were relatively well documented, and perhaps because the governance of such operators fitted better with late Victorian efforts to reform the profession, the ethical, self-assured and independent practitioners in the mould of Kind-Hart have received little positive attention.

The independent practice of dentistry which prevailed in America, ${ }^{5 \varsigma}$ and to which the best of the dentists of the late

${ }^{\S}$ Placed on a firm footing with the legal establishment of the Baltimore College of Dentistry in 1840. 
eighteenth century, and the great names of the Victorian profession (Tomes himself included ${ }^{26}$ ) in England belonged between 1745 (the end of the barber-surgeons as a united company) and 1860 (the first LDS examination), has been eclipsed in England.

However, the drive for self-governance of those who enter the profession and seek to act as independent ethical practitioners was not entirely suppressed and was sufficient to give dentists an NHS contract very different from the doctor's contract of $1951^{\text {If }}$ and to remove dentistry from the GMC with the institution of the GDC in 1956. This account by Chettle of just such a man working 430 years ago, serves as an invaluable reminder of the long-standing existence of this strand in those who serve the public through their profession.

" $\overline{\text { Based on item of service rather than doctor numbers }}$ or patient numbers.

1. Gross J J. The Rise and fall of the man of letters. p. 42. London: Weidenfeld and Nicholson, 1969

2. Dekker T. A knight's conjuring done in earnest. discovered in jest. London, 1607.

3. Chettle H. Kind-Heart's dreame. In Rimbault E F (ed) Early English poetry, ballads and popular literature of the middle ages: edited from original manuscripts and scarce publications. Vol. V. p 9. London: Percy Society, 1841.

4. Shakespeare W. King Lear: act V, scene 3 . London, 1606.

5. Chettle H. Kind-Heart's dreame. In Rimbault E F (ed) Early English poetry, ballads and popular literature of the middle ages: edited from original manuscripts and scarce publications. Vol. V. p v. London: Percy Society, 1841.
6. British Library copy. Chettle H. Kind-Harts Dreame conteining five apparitions, with their invectives against abuses raigning delivered by severall ghosts vnto him to be publisht, after piers penilesse post had refused the carriage, etc. C.14.a.6.

7. Halasz A. The marketplace of print: pamphlets and the public sphere in early modern England. Cambridge: Cambridge University Press, 1997.

8 Chettle H. Kind-Heart's dream. In Rimbault E F (ed) Early English poetry, ballads and popular literature of the middle ages: edited from original manuscripts and scarce publications. London: Percy Society, 1841. Online text available at http://www.archive. org/details/earlyenglishpoet05perc (accessed January 2012); Green N. Modern spelling transcript of Kind-Heart's dream from the Bodley Head edition of 1923 by G. B. Harrison, 2001. Online text available at http://www.oxford-shakespeare.com/Greene/ Kind-Heart's_Dream.pdf (accessed January 2012).

9. Jonson B. Bartholomew Fayre; Induction. London, 1714.

10. The National Archives, SP 12/130/17, ff. 34-6. pp1 Online article available at http://www.oxford-shakespeare.com/StatePapers12/SP_12-130-17_ff_34-6. pdf (accessed January 2012)

11. Halliday F E. Queen Elizabeth I and Dr Burcot: an episode of 1562. Hist Today 1955; 542-544.

12. Chettle H. Kind-Heart's dreame. In Rimbault E F (ed) Early English poetry, ballads and popular literature of the middle ages: edited from original manuscripts and scarce publications. Vol. V. pp 10-11. London: Percy Society, 1841.

13. Chettle H. Kind-Heart's dreame. In Rimbault E F (ed) Early English poetry, ballads and popular literature of the middle ages: edited from original manuscripts and scarce publications. Vol. V. p 28. London: Percy Society, 1841.

14 Chettle H. Kind-Hartes dedication of his dreame, to all the pleasant conceited whersoever. In Rimbault E F (ed) Early English poetry, ballads and popular literature of the middle ages: edited from original manuscripts and scarce publications. Vol. V. p vii. London: Percy Society, 1841.

15. Chettle H. Kind-Heart's dreame. In Rimbault E F (ed) Early English poetry, ballads and popular literature of the middle ages: edited from original manuscripts and scarce publications. Vol. V. p 29. London: Percy Society, 1841.

16. Chettle H. Kind-Heart's dreame. In Rimbault E F (ed) Early English poetry, ballads and popular literature of the middle ages: edited from original manuscripts and scarce publications. Vol. V. p 30. London: Percy Society, 1841.

17. Chettle H. Kind-Heart's dreame. In Rimbault E F (ed) Early English poetry, ballads and popular literature of the middle ages: edited from original manuscripts and scarce publications. Vol. V. p 29. London: Percy Society, 1841.

18. Lister. An account of a stone cut out from under the tongue of a man; lately sent in a letter of $\mathrm{Mr}$. Listers to his grace the Lord Arch-Bishop of York Phil Trans 1672; 7: 4062-4064.

19. Chettle H. Kind-Heart's dreame. In Rimbault E F (ed) Early English poetry, ballads and popular literature of the middle ages: edited from original manuscripts and scarce publications. Vol. V. p 21. London: Percy Society, 1841.

20. van Leeuwenhoek $A$. Part of two Letters from $\mathrm{Mr}$ Anthony Van Leewenhoek, F R S. concerning worms pretended to be taken from the teeth. Phil Trans 1700; 22: 635-642.

21. Chettle H. Kind-Heart's dreame. In Rimbault E F (ed) Early English poetry, ballads and popular literature of the middle ages: edited from original manuscripts and scarce publications. Vol. V. p 30. London: Percy Society, 1841

22. Chettle H. Kind-Heart's dreame. In Rimbault E F (ed) Early English poetry, ballads and popular literature of the middle ages: edited from original manuscripts and scarce publications. Vol. V. p 55. London: Percy Society, 1841.

23. Chettle H. Kind-Heart's dreame. In Rimbault E F (ed) Early English poetry, ballads and popular literature of the middle ages: edited from original manuscripts and scarce publications. Vol. V. p 27-28. London: Percy Society, 1841

24. Chettle H. Kind-Heart's dreame. In Rimbault E F (ed) Early English poetry, ballads and popular literature of the middle ages: edited from original manuscripts and scarce publications. Vol. V. p v. London: Percy Society, 1841.

25. Chettle H. Kind-Heart's dreame. In Rimbault E F (ed) Early English poetry, ballads and popular literature of the middle ages: edited from original manuscripts and scarce publications. Vol. V. pp 55-56. London: Percy Society, 1841

26. Bishop M. Parker M. Sir John Tomes F R S, Fellows of the Royal Society, and dental reform in the nineteenth century. Notes Rec $R$ Soc 2010 64: 401-416. 